\title{
THE UREA CLEARANCE OF YOUNG PREMATURE AND FULL TERM INFANTS ${ }^{1,2}$
}

\author{
BY HARRY H. GORDON, HAROLD E. HARRISON, AND HELEN MCNAMARA \\ (From the New York Hospital and the Department of Pediatrics, Cornell University Medical \\ College, New York City)
}

(Received for publication April 2, 1942)

In a previous study (1) of the nitrogen metabolism of premature infants, it was noted that edema developed in some infants when they were changed from diets of human milk to diets of cow's milk containing equivalent amounts of protein, fat, carbohydrate, and fluid. In subsequent studies of water and electrolyte exchange under similar dietary conditions (2), a lag in renal excretion of the extra sodium and chloride ingested in the cow's milk was found to accompany the large gain in weight. These observations suggested the present study to determine whether premature infants have a defect in kidney function. This seemed particularly desirable since the adequacy of renal function (3) presumably acts as a major determinant of minimal fluid requirements.

As a first approach to this problem, measurements were made of the 24-hour plasma urea clearance in a group of young prematurely born and full term infants. The results reported in this paper indicate that the urea clearance of premature infants is lower than that of full term infants of comparable postnatal age, and that in both groups the clearance is lower than that reported for older infants and adults. Moreover, the urea clearance of individual infants rose strikingly with increasing age. No relation was found to exist between urea clearance and urine flow for the group as a whole, and in each of 4 infants, augmentation of the urine flow from 25 to 100 per cent by increasing the fluid intake did not improve the urea clearance.

\section{METHODS \\ Subjects}

Fifteen healthy, male premature infants, ranging in age from 8 to 65 days and in weight from 1.6 to $3.4 \mathrm{kgm}$.,

\footnotetext{
1 Assistance in this work was given by the Children's Bureau, U. S. Department of Labor.

2 Presented in part before the meeting of the Society for Pediatric Research, Atlantic City, N. J., May 7, 1941. (Am. J. Dis. Child., 1941, 62, 894.)
}

were studied in 35 observations. Twelve observations were made in 9 male full term infants whose ages and weights ranged from 7 to 73 days, and from 2.8 to 4.9 kgm., respectively. All the infants were thriving at the time of study.

\section{Diets}

In all but one observation, the diets consisted of cow's milk $^{3}$ diluted with water and fortified in most instances with either cane sugar or dextrimaltose to provide an adequate caloric intake. In all but 4 observations (Tables II and III), the daily protein intake was high, i.e. from 4 to 6 grams per $\mathrm{kgm}$. The daily fluid intake was within the customary range of 130 to $185 \mathrm{cc}$. per $\mathrm{kgm}$. in all but 3 observations. All the infants received 10 or 20 drops daily of a vitamin $A$ and $D$ concentrate (percomorph oil) ; approximately half received daily supplements of 25 mgm. of ascorbic acid.

\section{Urine and blood}

Urine was collected (4), using toluol as a preservative, for carefully timed periods of approximately 24 hours. One-half to $1 \mathrm{cc}$. of venous or occasionally capillary blood was drawn into short tubes, containing either oxalate or heparin, at the beginning and end of the 24-hour period. Blood urea nitrogen was determined gasometrically, using the method of Van Slyke and Kugel (5). Urine urea and ammonia nitrogen were similarly determined and calculations of urea excretion made on the assumption that the ammonia appearing in the urine had been filtered through the glomeruli as urea. This was considered a fairer estimate of urea excretion (6) than the determination of urea alone since, in addition to the variable formation of ammonia from urea by the renal tubules, bacterial formation of ammonia in voided urine was not consistently prevented.4

The 24-hour clearance method used by Landis and his co-workers (7) is particularly suited to young infants for two reasons. Catheterization and washing out the bladder

3 The following preparations of cow's milk were used: evaporated or powdered whole milk, powdered halfskimmed milk (alacta), a powdered skimmed milk-olive oil preparation (olac), and a half-skimmed olac. The latter product was prepared specially by the Mead Johnson Co.

4 Urinary ammonia averaged 14 per cent of the total urinary urea plus ammonia and was less than 20 per cent in 34 of 40 observations in which the partition was determined (Tables II and III). 
to insure complete emptying may be omitted without introducing a large error, since the amount of urine retained by spontaneous incomplete voidings comprises only a relatively small fraction of the 24-hour urine flow (volume 75 to $400 \mathrm{cc}$. per 24 hours in these observations). Secondly, the feeding to these infants of their daily diets in 6 or 8 aliquots at 4 or 3 hour intervals tends to minimize fluctuations in blood urea (Table I).

TABLE I

Hourly variations in blood urea nitrogen

\begin{tabular}{|c|c|c|c|c|c|c|c|c|c|}
\hline \multirow{2}{*}{$\begin{array}{l}\text { Hours* } \\
\text { after } \\
\text { feeding }\end{array}$} & \multicolumn{7}{|c|}{ Blood urea nitrogen } & \multirow{2}{*}{$\begin{array}{c}\text { Aver- } \\
\text { age }\end{array}$} & \multirow{2}{*}{$\underset{\substack{\text { Maxi- } \\
\text { devia- } \\
\text { tion }}}{\substack{\text { mum } \\
\text { - }}}$} \\
\hline & 1 & $1\}$ & 2 & $2\}$ & 3 & $3 \frac{1}{2}$ & 4 & & \\
\hline Premature & \multicolumn{7}{|c|}{ mgm. per $100 \mathrm{cc}$. } & & $\begin{array}{l}\text { per cent } \\
\text { aserage }\end{array}$ \\
\hline T. R...... & & 23.7 & & 27.1 & & 23.8 & & 24.9 & 9 \\
\hline J. s........ & 33.4 & & 30.9 & & 31.8 & & 30.4 & 31.6 & 6 \\
\hline C. $\mathbf{M} . \ldots \ldots$ & & 17.0 & & 17.5 & & & & 17.3 & 2 \\
\hline C. T...... & 27.3 & & 29.6 & 27.4 & & & & 28.1 & 5 \\
\hline I. A........ & 25.9 & & 26.1 & & 24.0 & & & 25.3 & 8 \\
\hline $\begin{array}{c}\text { Full term } \\
\text { A. A.. } \ldots \ldots \ldots\end{array}$ & 20.4 & & & 20.9 & & & 20.1 & 20.5 & 2 \\
\hline F. M....... & 19.1 & & & 17.9 & & 18.4 & & 18.5 & 3 \\
\hline w. c....... & & & 20.1 & & 20.7 & 20.8 & & 20.5 & 2 \\
\hline T. T....... & & & & & $\begin{array}{l}27.4 \\
31.2\end{array}$ & & 29.8 & 29.5 & 7 \\
\hline J. R...... & & & & & \begin{tabular}{|l|}
26.9 \\
28.3
\end{tabular} & & 27.8 & 27.7 & 3 \\
\hline K. K....... & 17.5 & & 22.0 & & 16.1 & & 17.5 & 18.3 & 20 \\
\hline C. A....... & & & 17.9 & 19.3 & 19.8 & 19.9 & \begin{tabular}{|l|}
19.9 \\
18.5
\end{tabular} & 19.2 & 7 . \\
\hline
\end{tabular}

* Infants were fed every 3 or 4 hours throughout the 24 hours, and blood was drawn at the stated intervals following meals.

For each of 5 premature and 7 full term infants, urea nitrogen was determined in 3 or 4 samples of blood taken from 1 to 4 hours following the same or a similar feeding at different times of the day. The maximum deviation in any one specimen was, for 11 of the 12 infants, between 2 and 9 per cent of the average. In 1 infant (K. K.) the maximum deviation in a single specimen was 20 per cent of the average, but omission of this determination would have changed the average blood urea by only 8 per cent. It is of interest that the blood urea nitrogen of this group of thriving infants fed high protein diets (see also Tables II and III) is considerably higher than the customary levels found in adults.

\section{RESULTS}

The detailed results of the observations on premature and full term infants are presented in Tables II and III, respectively, and a summary of the results in Table IV.
TABLE II

Urea clearance of prematurely born infants

\begin{tabular}{|c|c|c|c|c|c|c|c|c|}
\hline \multirow[b]{2}{*}{ Subject } & \multirow[b]{2}{*}{ Age } & \multirow[b]{2}{*}{ Weight } & \multirow[b]{2}{*}{$\begin{array}{l}\text { Surface } \\
\operatorname{area}(a)\end{array}$} & \multicolumn{2}{|c|}{ Urine } & \multirow[b]{2}{*}{$\begin{array}{c}\text { Blood } \\
\text { urea } \\
\text { nitro- } \\
\text { gen }\end{array}$} & \multirow{2}{*}{\multicolumn{2}{|c|}{$\begin{array}{l}\text { Urea } \\
\text { clearance } \\
\text { cc. per } \\
\text { minute }\end{array}$}} \\
\hline & & & & $\begin{array}{l}\text { Vol- } \\
\text { ume }\end{array}$ & $\begin{array}{l}\text { Urea } \\
\text { and } \\
\text { am- } \\
\text { monia } \\
\text { nitro- } \\
\text { gen(b) }\end{array}$ & & & \\
\hline & days & grams & $\begin{array}{c}\text { sq. } \\
\text { meier }\end{array}$ & $\begin{array}{l}c c \text {. per } \\
\text { minute }\end{array}$ & $\begin{array}{c}\text { mgm. } \\
\text { per } \\
100 \mathrm{cc} .\end{array}$ & $\begin{array}{c}\text { mgm. } \\
\text { per } \\
100 \text { ce. }\end{array}$ & $U V / B$ & $\begin{array}{c}\text { per } \\
\text { sq. } \\
\text { meter }\end{array}$ \\
\hline F. L. & $\begin{array}{l}17 \\
65\end{array}$ & $\begin{array}{l}1600 \\
3205\end{array}$ & $\begin{array}{l}0.131 \\
0.221\end{array}$ & $\begin{array}{l}0.112 \\
0.259\end{array}$ & $\begin{array}{l}54 \\
64\end{array}$ & $\begin{array}{l}5.4(c) \\
6.5(c)\end{array}$ & $\begin{array}{l}1.1 \\
2.5\end{array}$ & $\begin{array}{r}8.5 \\
11.5\end{array}$ \\
\hline R. K. & $\begin{array}{l}27 \\
30\end{array}$ & & & & & & $\begin{array}{l}1.7 \\
1.8\end{array}$ & \\
\hline H. A. & $\begin{array}{l}10 \\
29 \\
50\end{array}$ & $\begin{array}{l}1890 \\
2520 \\
3630\end{array}$ & $\begin{array}{l}0.149 \\
0.184 \\
0.243\end{array}$ & $\begin{array}{l}0.131 \\
0.183 \\
.0 .254\end{array}$ & $\begin{array}{l}314 \\
464 \\
371\end{array}$ & $\begin{array}{l}23.9 \\
22.5 \\
19.8\end{array}$ & $\begin{array}{l}1.7 \\
3.8 \\
4.8\end{array}$ & \\
\hline W. B. & $\begin{array}{l}19 \\
23 \\
24 \\
40 \\
47\end{array}$ & $\begin{array}{l}1930 \\
1990 \\
2010 \\
2710 \\
2970\end{array}$ & $\begin{array}{l}0.151 \\
0.155 \\
0.156 \\
0.195 \\
0.209\end{array}$ & $\begin{array}{l}0.132 \\
0.139 \\
0.133 \\
0.110 \\
0.174\end{array}$ & $\begin{array}{l}350 \\
286 \\
342 \\
437 \\
461\end{array}$ & $\begin{array}{l}23.5 \\
22.1 \\
20.8 \\
17.6 \\
20.2\end{array}$ & $\begin{array}{l}2.0 \\
1.8 \\
2.2 \\
2.7 \\
4.0\end{array}$ & $\begin{array}{l}13.2 \\
11.6 \\
14.1 \\
13.8 \\
19.1\end{array}$ \\
\hline E. D. & 31 & 1953 & 0.152 & 0.064 & 830 & 21.9 & 2.4 & 15. \\
\hline A. G. & $\begin{array}{l}23 \\
24 \\
35\end{array}$ & $\begin{array}{l}1970 \\
2040 \\
2445\end{array}$ & $\begin{array}{l}0.153 \\
0.158 \\
0.180\end{array}$ & $\begin{array}{l}0.106 \\
0.127 \\
0.135\end{array}$ & $\begin{array}{l}346 \\
283 \\
370\end{array}$ & & $\begin{array}{l}1.8 \\
1.7 \\
2.6\end{array}$ & \\
\hline B. G. & $\begin{array}{l}18 \\
23 \\
31\end{array}$ & $\begin{array}{l}1985 \\
2170 \\
2510\end{array}$ & $\begin{array}{l}0.154 \\
0.165 \\
0.184\end{array}$ & $\begin{array}{l}0.126 \\
0.140 \\
0.173\end{array}$ & $\begin{array}{l}200 \\
392 \\
334\end{array}$ & & $\begin{array}{l}1.6 \\
2.1 \\
3.0\end{array}$ & $\begin{array}{l}10.5 \\
12.7 \\
16.3\end{array}$ \\
\hline P. A. & $\begin{array}{l}10 \\
29 \\
31 \\
45\end{array}$ & $\begin{array}{l}2125 \\
2750 \\
2800 \\
3410\end{array}$ & $\begin{array}{l}0.162 \\
0.197 \\
0.200 \\
0.232\end{array}$ & $\begin{array}{l}0.116 \\
0.195 \\
0.249 \\
0.242\end{array}$ & $\begin{array}{l}429 \\
547 \\
449 \\
523\end{array}$ & $\begin{array}{l}26.1 \\
32.7 \\
31.2 \\
27.1\end{array}$ & $\begin{array}{l}1.9 \\
3.3 \\
3.6 \\
4.7\end{array}$ & $\begin{array}{l}11.7 \\
16.8 \\
17.9 \\
20.3\end{array}$ \\
\hline J. S. & 19 & 2160 & 0.164 & 0.106 & 434 & 23.2 & 2.0 & 12.2 \\
\hline J. C. & $\begin{array}{r}8 \\
14 \\
43\end{array}$ & $\begin{array}{l}2200 \\
2360 \\
3260\end{array}$ & $\begin{array}{l}0.167 \\
0.176 \\
0.224\end{array}$ & $\begin{array}{l}0.133 \\
0.141 \\
0.248\end{array}$ & $\begin{array}{r}347 \\
99 \\
436\end{array}$ & $\begin{array}{l}22.4 \\
5.2(c) \\
21.3\end{array}$ & $\begin{array}{l}2.1 \\
2.7 \\
5.1\end{array}$ & $\begin{array}{l}12.6 \\
15.3 \\
22.8\end{array}$ \\
\hline T. $\mathbf{R}$. & $\begin{array}{l}21 \\
49 \\
58\end{array}$ & $\begin{array}{l}2209 \\
3035 \\
3340\end{array}$ & $\begin{array}{l}0.167 \\
0.212 \\
0.228\end{array}$ & $\begin{array}{l}0.080 \\
0.302 \\
0.208\end{array}$ & $\begin{array}{l}724 \\
391 \\
656\end{array}$ & $\begin{array}{l}26.6 \\
23.1 \\
24.9\end{array}$ & $\begin{array}{l}2.2 \\
5.1 \\
5.5\end{array}$ & $\begin{array}{l}13.2 \\
24.1 \\
24.1\end{array}$ \\
\hline v. C. & $\begin{array}{r}8 \\
10\end{array}$ & $\begin{array}{l}2393 \\
2385\end{array}$ & $\begin{array}{l}0.178 \\
0.177\end{array}$ & $\begin{array}{l}0.144 \\
0.230\end{array}$ & $\begin{array}{l}612 \\
322\end{array}$ & $\begin{array}{l}32.4 \\
27.4\end{array}$ & $\begin{array}{l}2.7 \\
2.7\end{array}$ & $\begin{array}{l}15.3 \\
15.3\end{array}$ \\
\hline R. L. & 27 & 2420 & 0.179 & 0.183 & 447 & 27.5 & 3.0 & 16.8 \\
\hline R. DeL. & 32 & 2555 & 0.186 & 0.226 & 157 & 13.4 & 2.6 & 14.2 \\
\hline A. $\mathbf{H}$. & 23 & 2965 & 0.208 & 0.139 & 674 & 21.2 & 4.4 & 21.3 \\
\hline
\end{tabular}

(a) Surface area for both premature and full term infants was calculated using the formula $5.188 \times \mathrm{wt} .78(8)$.

(b) Urea plus ammonia nitrogen was approximately 90 per cent of the total urinary nitrogen.

(c) These infants received a low protein diet.

In Table IV, the observations have been divided into two groups according to postnatal age. For both groups, under and over 30 days of age, the clearance was lower in premature than in full term infants. The mean clearance for the whole group of premature infants was $15.3 \mathrm{cc}$. per sq. meter per minute, as compared with $21.0 \mathrm{cc}$. for the full term infants. Although the ranges overlap, the difference of $5.7 \mathrm{cc}$. between the mean clearances is almost five times the probable error 
TABLE III

Urea clearance of full term infants

\begin{tabular}{|c|c|c|c|c|c|c|c|c|}
\hline \multirow[b]{2}{*}{ Subject } & \multirow[b]{2}{*}{ Age } & \multirow[b]{2}{*}{ Weight } & \multirow[b]{2}{*}{$\begin{array}{l}\text { Sur- } \\
\text { face } \\
\text { area }\end{array}$} & \multicolumn{2}{|c|}{ Urine } & \multirow[b]{2}{*}{$\begin{array}{c}\text { Blood } \\
\text { urea } \\
\text { nitrogen }\end{array}$} & \multirow{2}{*}{\multicolumn{2}{|c|}{$\begin{array}{l}\text { Urea } \\
\text { clearance } \\
\text { cc. per } \\
\text { minute }\end{array}$}} \\
\hline & & & & Vol- & $\begin{array}{l}\text { Urea } \\
\text { and } \\
\text { ammo- }\end{array}$ & & & \\
\hline & days & grams & $\begin{array}{c}s q . \\
\text { meter }\end{array}$ & $\begin{array}{l}\text { cc. per } \\
\text { minute }\end{array}$ & $\begin{array}{c}\text { mgm. } \\
\text { per } \\
100 \text { cc. }\end{array}$ & $\begin{array}{c}\text { mgm. } \\
\text { per } \\
100 \mathrm{cc} .\end{array}$ & $U V / B$ & $\begin{array}{c}\text { per } \\
\text { sq. } \\
\text { meter }\end{array}$ \\
\hline R. J. & 30 & 2790 & 0.199 & 0.220 & 398 & 23.8 & 3.7 & 18.5 \\
\hline W. C. & $\begin{array}{r}7 \\
27\end{array}$ & $\begin{array}{l}3255 \\
3700\end{array}$ & $\begin{array}{l}0.224 \\
0.246\end{array}$ & $\begin{array}{l}0.125 \\
0.146\end{array}$ & $\begin{array}{l}246 \\
648\end{array}$ & $\begin{array}{l}10.0^{*} \\
20.5\end{array}$ & $\begin{array}{l}3.1 \\
4.6\end{array}$ & $\begin{array}{l}13.8 \\
18.7\end{array}$ \\
\hline J. R. & 39 & 3730 & 0.248 & 0.229 & 660 & 27.8 & 5.4 & 21.7 \\
\hline W. D. & 14 & 4163 & 0.269 & 0.136 & 741 & 17.0 & 5.9 & 22.0 \\
\hline K. K. & $\begin{array}{l}71 \\
73\end{array}$ & $\begin{array}{l}4200 \\
4275\end{array}$ & $\begin{array}{l}0.271 \\
0.274\end{array}$ & $\begin{array}{l}0.136 \\
0.270\end{array}$ & $\begin{array}{r}1049 \\
515\end{array}$ & $\begin{array}{l}18.3 \\
16.2\end{array}$ & $\begin{array}{l}7.8 \\
8.6\end{array}$ & $\begin{array}{l}28.8 \\
31.3\end{array}$ \\
\hline D. S. & 59 & 4280 & 0.275 & 0.256 & 507 & 19.3 & 6.7 & 24.5 \\
\hline T. T. & $\begin{array}{l}27 \\
41\end{array}$ & $\begin{array}{l}4360 \\
4860\end{array}$ & $\begin{array}{l}0.278 \\
0.302\end{array}$ & $\begin{array}{l}0.191 \\
0.188\end{array}$ & $\begin{array}{l}748 \\
691\end{array}$ & $\begin{array}{l}30.5 \\
25.7\end{array}$ & $\begin{array}{l}4.7 \\
5.1\end{array}$ & $\begin{array}{l}16.8 \\
16.7\end{array}$ \\
\hline G. M. & 54 & 4530 & 0.286 & 0.156 & 689 & 15.2 & 7.1 & 24.7 \\
\hline V. F. & 23 & 4600 & 0.290 & 0.099 & 662 & 16.1 & 4.1 & 14.1 \\
\hline
\end{tabular}

* This infant received a relatively low protein intake (3 grams per kgm.).

TABLE IV

Urea clearance of premature and full term infants. Summary of results

\begin{tabular}{|c|c|c|c|c|c|c|}
\hline \multirow{3}{*}{ Postnatal age } & \multicolumn{3}{|c|}{ Premature infants } & \multicolumn{3}{|c|}{ Full term infants } \\
\hline & \multirow{2}{*}{$\begin{array}{l}\text { Num- } \\
\text { ber } \\
\text { of ob- } \\
\text { serva- } \\
\text { tions }\end{array}$} & \multicolumn{2}{|c|}{ Urea clearance } & \multirow{2}{*}{$\begin{array}{l}\text { Num- } \\
\text { ber } \\
\text { of ob- } \\
\text { serva- } \\
\text { tions }\end{array}$} & \multicolumn{2}{|c|}{ Urea clearance } \\
\hline & & Mean & Range & & Mean & Range \\
\hline & & \multicolumn{2}{|c|}{$\begin{array}{l}\text { cc. per sq. meler } \\
\text { per minute }\end{array}$} & & \multicolumn{2}{|c|}{$\begin{array}{l}\text { cc. per sq. meter } \\
\text { per minute }\end{array}$} \\
\hline $\begin{array}{l}\text { Less than } 30 \text { days. . } \\
30 \text { days and over... }\end{array}$ & $\begin{array}{l}21 \\
14\end{array}$ & $\begin{array}{l}13.7 \\
17.6\end{array}$ & $\begin{array}{r}8.5-21.3 \\
11.5-24.1\end{array}$ & $\begin{array}{l}6 \\
6\end{array}$ & $\begin{array}{l}17.3 \\
24.6\end{array}$ & $\begin{array}{l}13.8-22.0 \\
16.7-31.3\end{array}$ \\
\hline Total............ & 35 & $\begin{array}{c}15.3^{*} \\
\pm \\
\text { P.E. } 0\end{array}$ & $8.5-24.1$ & 12 & $\begin{array}{c}21.0^{*} \\
\pm \\
\text { P.E. } 1\end{array}$ & $13.8-31.3$ \\
\hline
\end{tabular}

* Difference between means is $5.7 \pm 1.18$.

of the difference. The mean clearances for both groups of young infants (15 and $21 \mathrm{cc}$.) are considerably lower than the average clearance of 38 cc. per sq. meter per minute (range 23 to $55 \mathrm{cc}$.) found in older infants by Schoenthal (9), and the "standard" and "maximum" clearances of adults, 30 and $40 \mathrm{cc}$. per sq. meter per minute (10). Since, as will be shown later, the clear- ances in these young infants were "maximum" at the time of observation, i.e., increasing the urine flow did not increase the clearance, there can be no doubt that young infants, both premature and full term, have a defect in urea clearance when compared with older infants and adults. Evidence confirming the existence of this defect in young infants has recently been published (11).

\section{Effect of increasing size and postnatal age on urea clearance}

The effect of increasing maturation as measured by increasing size and age on urea clearance is indicated in Figure 1, in which repeated observations on 8 premature and 2 full term infants are presented. The ages at the initial and final observations for each infant are also indicated. It is seen that a rise in clearance took place in each of the 8 premature and in 1 of the 2 full term infants as they grew larger and older. The figure also gives some measure of the variability in clearance between infants of similar size as well as age.

Infant F. L. (premature), who showed a low clearance at both 17 and 65 days of age, was the only infant on a low protein diet at the time of both observations. It has been reported (12) that under certain conditions low protein diets depress the urea clearance and this may have contributed to the persistently low findings for this infant. Further work is needed to elucidate this point.

TABLE V

Effect of increased urine flow on 24hour urea clearance

\begin{tabular}{|c|c|c|c|c|c|c|c|c|}
\hline \multirow[b]{2}{*}{ Subject } & \multirow[b]{2}{*}{ Age } & \multirow[b]{2}{*}{ Weight } & \multirow[b]{2}{*}{$\begin{array}{l}\text { Fluid } \\
\text { in- } \\
\text { take }\end{array}$} & \multicolumn{3}{|c|}{ Urine } & \multirow{2}{*}{$\begin{array}{c}\text { Blood } \\
\text { urea } \\
\text { nitro- } \\
\text { gen }\end{array}$} & \multirow[b]{2}{*}{$\begin{array}{c}\text { Urea } \\
\text { clearance }\end{array}$} \\
\hline & & & & \multicolumn{2}{|c|}{ Volume } & $\begin{array}{c}\text { Urea } \\
\text { and } \\
\text { ammo }\end{array}$ & & \\
\hline & deys & grams & $\begin{array}{c}\text { cc. } \\
\text { per } \\
\text { kgm. }\end{array}$ & $\begin{array}{c}c c . \\
\text { per } \\
\text { min- } \\
\text { ute }\end{array}$ & $\begin{array}{c}\text { cc. per sq. } \\
\text { meler per } \\
\text { minute }\end{array}$ & $\begin{array}{c}\text { mgm. } \\
\text { per } \\
\text { cent }\end{array}$ & $\begin{array}{c}\text { mgm. } \\
\text { per } \\
\text { cent }\end{array}$ & $\begin{array}{c}\text { cc. per sq. } \\
\text { meter per } \\
\text { minute }\end{array}$ \\
\hline R. K. & $\begin{array}{l}27 \\
30\end{array}$ & $\begin{array}{l}1800 \\
1915\end{array}$ & $\begin{array}{l}111 \\
146\end{array}$ & $\begin{array}{l}0.05 \\
0.10\end{array}$ & $\begin{array}{l}0.36 \\
0.64\end{array}$ & $\begin{array}{l}859 \\
464\end{array}$ & $\begin{array}{l}26.4 \\
23.2\end{array}$ & $\begin{array}{l}11.8 \\
11.9\end{array}$ \\
\hline V. C. & $\begin{array}{r}8 \\
10\end{array}$ & $\begin{array}{l}2393 \\
2385\end{array}$ & $\begin{array}{l}133 \\
218\end{array}$ & $\begin{array}{l}0.14 \\
0.23\end{array}$ & $\begin{array}{l}0.81 \\
1.30\end{array}$ & $\begin{array}{l}612 \\
323\end{array}$ & $\begin{array}{l}32.4 \\
27.4\end{array}$ & $\begin{array}{l}15.3 \\
15.3\end{array}$ \\
\hline P. A. & $\begin{array}{l}29 \\
31\end{array}$ & $\begin{array}{l}2750 \\
2800\end{array}$ & $\begin{array}{l}145 \\
186\end{array}$ & $\begin{array}{l}0.20 \\
0.25\end{array}$ & $\begin{array}{l}0.99 \\
1.25\end{array}$ & $\begin{array}{l}547 \\
449\end{array}$ & $\begin{array}{l}32.7 \\
31.2\end{array}$ & $\begin{array}{l}16.6 \\
17.9\end{array}$ \\
\hline K. K. & $\begin{array}{l}71 \\
73\end{array}$ & $\begin{array}{l}4200 \\
4275\end{array}$ & $\begin{array}{l}136 \\
182\end{array}$ & $\begin{array}{l}0.14 \\
0.27\end{array}$ & $\begin{array}{l}0.50 \\
0.98\end{array}$ & $\begin{array}{r}1084 \\
515\end{array}$ & $\begin{array}{l}18.3 \\
16.2\end{array}$ & $\begin{array}{l}29.8 \\
31.3\end{array}$ \\
\hline
\end{tabular}




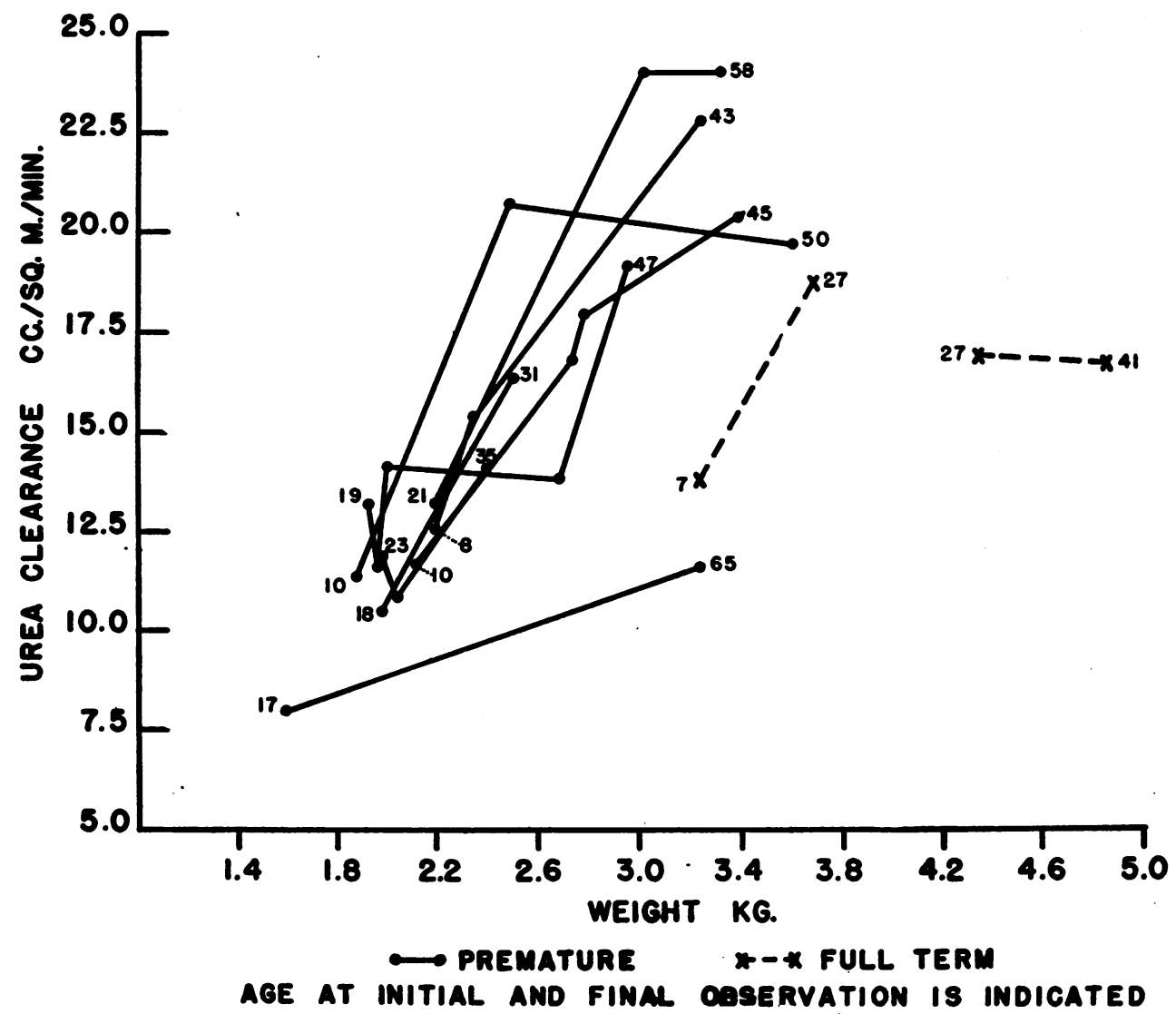

Fig. 1. The Relation of Increasing Size and Days of Age to Urea Clearance in INDIVIDUAL INFANTS

\section{Effect of variations in urine flow on urea clearance}

Because the urine flows for most of the infants were below the arbitrary "augmentation" limit for adults of approximately 0.9 to $1.2 \mathrm{cc}$. per sq. meter per minute (i.e. 1.5 to $2.0 \mathrm{cc}$. per minute), the effect of increasing the urine flow on the urea clearance was studied in 4 infants. In each of these infants, the urea clearance was determined at two levels of fluid intake, at least 24 hours of the altered intake elapsing before the second observation began. Increasing the fluid intake increased the initial urine flows of 0.4 to $1.0 \mathrm{cc}$. per sq. meter per minute by from 25 to 100 per cent, but this was accompanied by a proportional decrease in urinary concentration of urea. Since the blood urea did not change greatly, the clearances remained constant. This lack of relation of urine flow, within the ranges studied, to urea clearance is confirmed by the low coefficient of corre- lation $(0.17 \pm 0.09)$ between urea clearance and urine flow computed for the whole group of observations (Tables II and III).

These results are not in accord with the conclusions of McCance and his coworkers (11), who using uncatheterized specimens collected over probably short periods, reported a direct relationship between the urea clearance and the minute volume of urine. They considered this relationship as affording added evidence for instability of renal function in young infants. The discrepancy may be explained in part by the fact that most of the infants studied by McCance and his coworkers were less than 14 days of age, and it may be that in very young infants under conditions of low fluid intakes and very low urine flows (e.g., $0.2 \mathrm{cc}$. per sq. meter per minute) (11) there is a direct relation between urea clearance and urine flow. The reported results, however, show a large scatter. Furthermore, estimations of urea clearance from 
spontaneously voided specimens over short periods permit the introduction of a significant systematic error which would show low urea clearances for low urine volumes and large clearances for large volumes. Either catheterized specimens for short periods of time or long periods of collections such as were used in the present study are necessary to minimize this source of error. Suffice it to say that using the 24-hour method, no relation was found in the present study between urine flow and urea clearance, this lack of correlation being evident in an 8-day-old premature infant and in a full term infant of 70 days, over a range of clearances of from 12 to $30 \mathrm{cc}$. per sq. meter per minute, and over a range of initial urine flows of from 0.4 to $1.0 \mathrm{cc}$. per sq. meter per. minute.

\section{DISCUSSION}

The low urea clearance of young infants may be caused by diminished glomerular filtration or increased tubular reabsorption of urea. Shannon (13) has demonstrated that with low urine flows there is an increased reabsorption of urea, possibly due to prolonged contact of urine with the cells of the reabsorbing tubules. The lack of correlation in the whole group of observations between urine flow and urea clearance, and the lack of effect in 4 infants of sharp rises in urine flow on urea clearance, suggest that increased tubular reabsorption of urea due to low urine flow is not the cause for the low urea clearances observed in this study.

The other explanation for diminished urea clearances is a decreased glomerular filtration. We have not yet had the opportunity to measure simultaneous inulin and urea clearances in young infants, but Barnett (14) has reported that the rate of removal of inulin from the blood is slower in full term infants of 5 to 9 days than in infants of 2 to 7 weeks, and that in both groups the rate is slower than in children of 6 to 10 years. Although, as has been pointed out (15), these data are inadequate for quantitative interpretation of the blood inulin curves in terms of clearance, Barnett's explanation would account for the higher urea clearances in older infants noted by McCance and Young (11a) and those reported in the present study.
Histological studies (16) of the glomeruli of the fetus and newborn infant supply anatomical support for the supposition of defective glomerular filtration. The earlier the stage of development of the kidney, the fewer the rows of glomeruli in the cortex, and the less convoluted the capillaries. The actual amount of blood coursing through the glomeruli and the size of the filtering surface may thus be limited by the state of development of the glomeruli. Another factor limiting filtration is the extent of the layer of cuboidal cells lining the glomerulus. The shedding of this layer may be wholly developmental or it may be partly dependent on postnatal circulatory changes. Finally, glomerular dynamics in these young infants may be conditioned by postnatal physiologic adjustments of a systemic rather than solely renal character.

Studies of inulin and diodrast clearance may throw light on the mechanisms involved. Definition of the relation of defective renal function in young infants to peculiarities in water and acidbase metabolism (17) and to such clinical states as dehydration fever, acidosis and tetany in the newborn period must await completion of studies of tubular function.

\section{SUM MARY}

The 24-hour plasma clearance of urea was determined in 35 observations on 15 premature infants and in 12 observations on 9 full term infants, ranging in age from 8 to 65 and from 7 to 73 days, respectively. The urea clearance is lower in premature than in full term infants, and in both groups of young infants it is lower than that reported for older subjects. No relation was found to exist between urine flow and urea clearance.

\section{BIBLIOGRAPHY}

1. Gordon, H. H., Levine, S. Z., Wheatley, M. A., and Marples, E., Respiratory metabolism in infancy and in childhood. XX. The nitrogen metabolism in premature infants. Comparative studies of human milk and cow's milk. Am. J. Dis. Child., 1937, 54, 1030.

2. Gordon, H. H., and Levine, S. Z., Unpublished observations.

3. Gamble, J. L., Extracellular fluid: Extracellular fluid and its vicissitudes. Bull. Johns Hopkins Hosp., 1937, 61, 151; Extracellular fluid: Renal defense of extracellular fluid; control of acid-base excre- 
tion and the factors of water expenditure. Ibid., 1937, 61, 174.

4. Hoag, L. A., Apparatus for quantitative collection of urine and of stools in male infants. Am. J. Dis. Child., 1932, 44, 770.

5. Van Slyke, D. D., and Kugel, V. H., Improvements in manometric micro-kjeldahl and blood urea methods. J. Biol. Chem., 1933, 102, 489.

6. Van Slyke, D. D., Page, I. H., Hiller, A., and Kirk, E., Studies of urea excretion. IX. Comparison of urea clearances calculated from the excretion of urea, of urea plus ammonia and of nitrogen determinable by hypobromite. J. Clin. Invest., 1935, 14, 901.

7. Landis, E. M., Elsom, K. A., Bott, P. A., and Shiels, E., Observations on sodium chloride restriction and urea clearance in renal insufficiency. J. Clin. Invest., 1935, 14, 525.

8. Klein, A. D., and Scammon, R. E., Relations between surface area, weight and length of the human body in prenatal life. Proc. Soc. Exper. Biol. and Med., 1930, 27; 456.

9. Schoenthal, L., Lurie, D., and Kelly, M., Urea clearance in normal and in dehydrated infants. Renal function in intestinal intoxication. Am. J. Dis. Child., 1933, 45, 41.

10. a. Peters, J. P., and Van Slyke, D. D., Quantitative Clinical Chemistry, Vol. I. Interpretations. The Williams and Wilkins Co., Baltimore, 1931, pp. 345-347.

b. Smith, H. W., The Physiology of the Kidney. Oxford University Press, New York, 1937.

11. a. McCance, R. A., and Young, W. F., The secretion of urine by newborn infants. J. Physiol., 1941, 99, 265.

b. Young, W. F., Hallum, J. L., and McCance, R. A., The secretion of urine by premature infants. Arch. Dis. Child., 1941, 16, 243.

12. a. Cope, C. L., Studies of urea excretion. VIII. The effects on the urea clearance of changes in protein and salt contents of the diet. J. Clin. Invest., 1933, $12,567$. b. Goldring, W., Razinsky, L., Greenblatt, M., and Cohen, $S$., The influence of protein intake on the urea clearance in normal man. J. Clin. Invest., 1934, 13, 743.

c. Farr, L. E., The effect of dietary protein on the urea clearance of children with nephrosis. J. Clin. Invest., 1936, 15, 703.

13. Shannon, J. A., Glomerular filtration and urea excretion in relation to urine flow in the dog. Am. J. Physiol., 1936, 117, 206.

14. Barnett, H. L., Renal physiology in infants and children: I. Method for estimation of glomerular filtration rate. Proc. Soc. Exper. Biol. and Med., 1940, 44, 654.

15. Herrin, R. C., Factors affecting the tests of kidney function. Physiol. Rev., 1941, 21, 529.

16. a. Peter, K., Untersuchungen über Bau und Entwicklung der Niere. Vol. I and II. G. Fischer, Jena, 1909-1927.

b. Clara, M., Vergleichende Histobiologie des Nierenglomerulus und der Lungenalveole. Ztschr. f. mikr.-anat. Forsch., 1936, 40, 147.

c. Gruenwald, P., and Popper, H., The histogenesis and physiology of the renal glomerulus in early postnatal life: histological examinations. J. Urol., $1940,43,452$.

17. a. Yllpö, A., Neugeborenen: Hunger; und Intoxicationsacidosis in ihren Beziehungen zueinander. Ztschr. f. Kinderh., 1916, 14, 268.

b. Hoag, L. A., and Kiser, W. H., Jr., Acid-base equilibrium of newborn infants. I. Normal standards. Am. J. Dis. Child., 1931, 41, 1054.

c. Marples, E., and Lippard, V. W., Acid-base balance of new-born infants. II. Consideration of the low alkaline reserve of normal new-born infants. Am. J. Dis. Child., 1932, 44, 31.

d. Adolph, E. F., Postnatal development of water diuresis. Am. J. Physiol., 1941, 133, 191.

e. Branning, W. S., The acid-base balance of premature infants. J. Clin. Invest., 1942, 21, 101.

f. Räihä, C. E., Säuglingsmortalität und Frühgeburtlichkeit-Uber einige Neugeborenenprobleme. Acta Paediatrica, 1941, 28, 390. 